\title{
16. CHEMICAL AND MINERALOGICAL STUDIES, SITE 66
}

\author{
James I. Drever, Scripps Institution of Oceanography, La Jolla, California
}

\section{INTRODUCTION}

Site 66 is located in the Central Pacific Basin under the present equatorial high productivity zone. The basal 27 meters of sediment cored at this site, however, contain no calcareous remains, and only a few corroded siliceous fossils of middle Cretaceous age, in one layer close to the basement. The present study was undertaken to try to determine the origin of the clay section, and hence to contribute to an understanding of the geological history of the Central Pacific Ocean. The rate of sedimentation appears to be very low. The paleontological data (see Site Reports) suggest a rate of $0.5 \mathrm{~m} / 10^{6} \mathrm{yr}$, assuming continuous deposition, and the magnetic data (Chapter 27) are consistent with this value.

The techniques used were $\mathrm{X}$-ray diffraction using a modified G.E. XRD-5 equipped with solid state detector (Drever and Fitzgerald, 1970), electron microscopy using a Siemens Elmiskop II, and energy dispersion X-ray fluorescence analysis (Fitzgerald and Gantzel, 1970).

\section{DESCRIPTION AND MINERALOGY}

The upper 21.5 meters of the section examined (66.0-6-2 to 66.0-8-6) are a fine-grained, stiff pelagic clay, with intense light brown, dark brown, and brownish-black mottling. The less than 2 micron-size fraction (equivalent spherical diameter) of this sediment (typically 80 to 90 per cent of the total, see Chapter 00) contained typically 40 per cent palygorskite, 30 per cent mica, 20 per cent montmorillonite, 5 per cent kaolinite plus chlorite, 3 per cent quartz (using the method of mutual ratios and the weighting factors of Rex, 1969). The clay mineralogy is rather uniform over the 21.5-meter section; the only significant trend is a general decrease in the montmorillonite/mica ratio up the core (Figure 1). The absolute accuracy of these numbers is poor, probably no better than \pm 20 per cent, however the precision in comparing one sample with another is much better, approximately \pm 5 per cent of the amount present for the major phases. The presence of kaolinite and chlorite was inferred from the presence of clearly resolved X-ray diffraction peaks at $3.53 \AA$ and $3.58 \AA$, together with peaks at $7.1 \AA$ and $14.1 \AA$. After acid solution the $14.1 \AA$ peak and the $3.53 \AA$ peak disappeared, and the $3.58 \AA$ peak was unaffected. After heat treatment at $600^{\circ} \mathrm{C}$ for one hour the $3.3 .58 \AA$ peak disappeared and the $3.53 \AA$ and $14.1 \AA$ peaks were unaffected.
The clay shows a bimodal size distribution. Montmorillonite and palygorskite are largely finer than $0.5 \mu$ e.s.d., and mica, quartz, kaolinite, and chlorite are generally coarser than $1 \mu$ (Plate 1$)$.

The principal minerals of the greater than 2 micron-size fraction are mica, quartz, feldspar, kaolinite and chlorite. Traces of amphibole were observed in some samples. The mica is well-crystallized, and appears to be predominantly $2 \mathrm{M}_{1}$ muscovite, although a complete characterization is not possible in such a complex mixture. The feldspar peaks are consistent with a mixture of alkali feldspar and plagioclase in an approximate 2:1 ratio; again, it is impossible to characterize the feldspars completely in such a complex mixture.

The basal 4 meters of the core (Core 9) are strongly banded (Figure 1). There are layers of pelagic clay similar to that described above, layers of hyaloclastic debris, red, brown, and yellow in color, containing altered rock fragments up to 2 centimeters in diameter, and layers of brownish-black ferromanganese oxide containing occasional hyaloclastic fragments. One altered rock fragment $(66.0-9-1,99-100 \mathrm{~cm})$ consisted of montmorillonite (predominantly dioctahedral, $\mathrm{b}_{\mathrm{O}}=$ 9.06) and a high structural-state alkali feldspar (sanidine or anorthoclase). The $<2 \mu$ fraction of the hyaloclastic layers varies from pure montmorillonite $\left(b_{0}=9.05\right)$ to montmorillonite plus various admixtures of the mica-palygorskite-quartz suite. Heulandite/ clinoptilolite was tentatively identified as a minor component of $66.0-9-3,127-128 \mathrm{~cm}$ (Plate 2).

The samples from the brownish-black layers (66.0-9-3, $28-29 \mathrm{~cm}, 38-39 \mathrm{~cm}, 103-104 \mathrm{~cm}$ and $147-148 \mathrm{~cm})$ are largely X-ray amorphous, with minor goethite (Plate 3 ) and traces of clay minerals. The X-ray amorphous material is extremely fine-grained but appears to form stable aggregates which do not disperse in water, even when ultrasonic dispersion is used. These aggregates may be related to the amorphous iron oxide spherules described on Leg 5 by von der Borch and Rex (1970), and on Leg 8 by von der Borch, Nesteroff and Galehouse (1970). The presence of crystalline goethite and the failure to disperse in water suggest that the material described here has undergone more advanced diagenesis than the material described from Legs 5 and 8. 


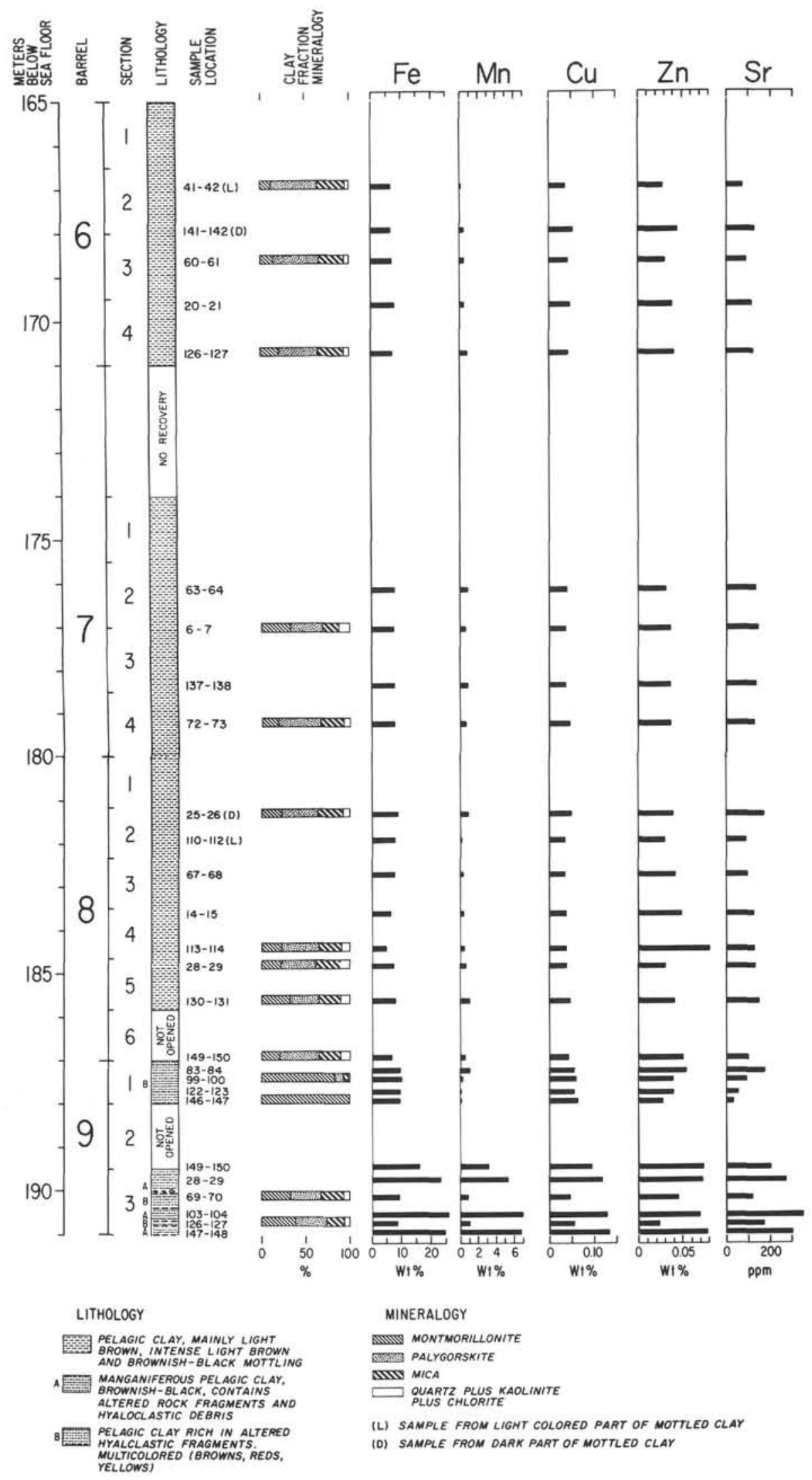

Figure 1. Chemistry and mineralogy, Core 66.0. 


\section{Chemistry}

Semi-quantitative chemical analyses of untreated core samples were made by energy dispersion X-ray fluorescence spectrometry (Fitzgerald and Gantzel, 1970). In this technique, the entire X-ray spectrum is recorded simultaneously, so that sufficient data for analysis of major and minor elements can be collected in a short period of time. An integration time of $200 \mathrm{sec} / \mathrm{sample}$ was used for the analyses in Figure 1. The more precise analysis of 66.0-9-3, 103-104 cm (Table 1) was performed on powdered sediment dried at $110^{\circ} \mathrm{C}$, using an integration time of 8000 seconds. The particular instrument used had a fairly long air path, so that it was not possible to obtain analytical data for elements of atomic number less than potassium. Initially an analysis of Sample 66.0-9-3, 103-104 was calculated using G-2 and W-1 (U.S. Geological Survey standard analyzed rocks) as standards. An artificial standard was then prepared with the calculated composition of 66.0-9-3, 103-104. The analysis of Sample 66.-9-3, 103-104 was then made using this artificial standard as a standard, so that matrix effects are largely eliminated. The remaining samples were analyzed using 66.0-9-3, 103-104 as a standard; empirical corrections were made for the absorption of copper and zinc radiation by iron and manganese. The results in Figure 1 are presented as weight per cent of the sample dried at $110^{\circ} \mathrm{C}$, although the samples were analyzed wet. The fluorescent X-ray intensities are rather insensitive to variations in water content, so that this conversion does not introduce significant uncertainties. For reasons of equipment failure, the comparison of 66.0-9-3, 103-104 with the artificial standard was made using a conventional wavelength spectrometer, which permitted analysis for silicon and molybdenum, but resulted in rather large analytical uncertainties. The uncertainty in the absolute values for 66.0-9-3, 103-104 are shown in Table 1. The precision of the values in Figure 1 is approximately \pm 3 per cent of the amount present for iron and manganese, \pm 5 per cent for strontium and copper, \pm 7 per cent for zinc.

\section{TABLE 1}

Semi-quantitative Analysis of a Ferromanganese Oxide Layer, 7-66.0-9-3 $(103-104 \mathrm{~cm})$

\begin{tabular}{lrlc}
\hline \multicolumn{2}{l}{ Wt $\%$} & \multicolumn{2}{c}{ ppm } \\
\hline $\mathrm{Fe}$ & $26.00 \pm 1.00$ & $\mathrm{Ba}$ & $4100 \pm 200$ \\
$\mathrm{Mn}$ & $7.00 \pm 1.00$ & $\mathrm{Sr}$ & $350 \pm 50$ \\
$\mathrm{Ni}$ & $0.10 \pm 0.03$ & $\mathrm{Rb}$ & $12 \pm 5$ \\
$\mathrm{Cu}$ & $0.13 \pm 0.02$ & $\mathrm{~V}$ & $1100 \pm 200$ \\
$\mathrm{Zn}$ & $0.07 \pm 0.02$ & $\mathrm{Cr}$ & $150 \pm 50$ \\
$\mathrm{Ca}$ & $1.50 \pm 0.30$ & $\mathrm{As}$ & $300 \pm 150$ \\
$\mathrm{SiO}_{2}$ & $17.00 \pm 3.00$ & $\mathrm{Mo}$ & $50 \pm 20$ \\
\hline
\end{tabular}

The brownish-black layers near the base of the core are highly enriched in iron, manganese, nickel, copper, zinc, vanadium, arsenic, and molybdenum compared to "normal" pelagic sediment (Cronan, 1969; Boström and Peterson, 1969). Two samples from the pelagic clay section of the core (66.0-6-2, 141-142 and 66.0-8-2, 25-26) were selected to include as much of possible of the dark mottling material, and two samples (66.0-6-2, 41-42 and 66.0-8-2, 110-112) were selected to exclude the dark material as far as possible (see Figure 1). It is apparent that the darker color is caused by a higher manganese-oxide concentration.

Overall, there is a high correlation between iron, manganese, copper, strontium, and arsenic (arsenic is measurable only in the ferromanganese-oxide layers). This suggests that these elements are deposited by a single mechanism, and that there has been little post-depositional migration of these elements. Other elements (not plotted in Figure 1) which covary with iron and manganese are calcium and barium, while potassium and rubidium correlate negatively with iron. Zinc shows a somewhat different distribution. There is a general correlation between manganese and zinc, however high values of zinc occur in Core 8 which do not correspond to high values of iron, manganese or copper. There is, however, a possibility of contamination by high zinc grease used in drilling (C. C. von der Borch, personal communication).

\section{DISCUSSION}

The sediments in the basal 27 meters of Core 66.0 can be divided into three components: A ferromanganeseoxide component, a hyaloclastic component derived presumably from local volcanism, and a pelagic clay component, derived in large part from the continents. The ferromanganese-oxide material is chemically very similar to Recent sediments found at the crest of the East Pacific Rise (Bostrom and Peterson, 1966, 1969; Bostrom et al, 1969). According to these authors, the sediments are a precipitate formed when iron-rich hydrothermal solutions are introduced into the ocean through the sea floor. The alternation of almost pure ferromanganese layers with pelagic sediment layers indicates that the ferromanganese oxides were formed syngenetically and not introduced into the sediment subsequent to deposition. The only recent occurrences of such sediments are on active spreading centers, and it is reasonable to assume that Site 66 was at the crest of an active spreading center in middle Cretaceous time. The lower concentration of iron and manganese in the higher sections would be explained by the crust on which Site 66 is located moving away from the spreading center, and hence away from the hydrothermal source. A similar model has been used to explain the basal ferromanganese facies encountered in Deep Sea Drilling cores in the Atlantic (Boström, 
1970), and in the Eastern Pacific (von der Borch and Rex, 1970; von der Borch, Nesteroff and Galehouse, 1970).

The mica-quartz-kaolinite-chlorite assemblage must be continental in origin. With the exception of the palygorskite, it is similar in mineralogy and sizedistribution to present-day atmospheric dust (Windom, 1969; Prospero and Bonatti, 1969), although there is no direct evidence for eolian transport. The extremely slow sedimentation rate (see Site Reports) indicates that Site 66 was not in a position to receive any large amount of land-derived material.

A striking feature of the section examined is the complete absence of calcareous remains, and the almost complete absence of siliceous skeletal remains. This suggests that during the time interval Middle Cretaceous to Oligocene Site 66 was always below the carbonate compensation depth, and was not under a zone of high organic productivity. The siliceous remains observed in Core 9 were corroded, indicating that some silica could have been dissolved. It does not seem likely, however, that siliceous organisms could have made up a very large percentage of the original sediment.

The origin of the palygorskite is at present obscure. Its distribution is quite uniform within the terrigenous suite, and it is absent or minor in the hyaloclastic suite. It is therefore not an alteration product of locallyderived volcanic material. If it is an alteration product of some other material, for example olivine, pyroxene, volcanic glass, it is very hard to conceive of a source of sediment of suitable composition which could remain stable over the time interval represented by Cores 6,7 and 8. Similarly, the introduction of silica-rich solutions into the bottom-waters could cause precipitation of palygorskite, but it is unlikely that such a source could proceed so uniformly over such a long time-span. A possible explanation is that palygorskite is formed by reaction between magnesium-rich solutions resulting from alteration of the underlying basalt, and biogenic silica, which might originally have been uniformly distributed through the pelagic clay section.

\section{Acknowledgements}

The author wishes to thank J. Greenslate and R. Fitzgerald for assistance in performing the chemical analyses, P. Gantzel for contributing his time and equipment after the energy spectrometer became inoperative, and S. S. Liang for preparing the electron micrographs. The work was supported in part by Kennecott Exploration Company through a grant to $\mathrm{G}$. Arrhenius and R. W. Fitzgerald.

\section{REFERENCES}

Boström, K., 1970. Geochemical evidence for ocean floor spreading in the South Atlantic Ocean. $\mathrm{Na}$ ture. 227, 1941.

Boström, K. and Peterson, M. N. A., 1966. Precipitates from hydrothermal exhalations on the East Pacific Rise. Econ. Geol. 61, 1258.

Boström, K. and Peterson, M. N. A., 1969. The origin of the aluminum-poor ferromanganoan sediments in areas of high heat-flow on the East Pacific Rise. Marine Geol. 7, 427.

Boström, K., Peterson, M. N. A., Joensuu, O. and Fisher, D. E., 1969. Aluminum-poor ferromanganoan sediments on active oceanic ridges. $J$. Geophys. Res. 74, 3261 .

Cronan, D. S., 1969. Average abundances of Mn, Fe, $\mathrm{Ni}, \mathrm{Co}, \mathrm{Cu}, \mathrm{Pb}, \mathrm{Mo}, \mathrm{V}, \mathrm{Cr}, \mathrm{Ti}$ and $\mathrm{P}$ in Pacific pelagic clays. Geochim. Cosmochin. Acta. 33,1562.

Drever, J. I. and Fitzgerald, R. W., 1970. Fluorescence elimination in X-ray diffractometry with solid state detectors. Mat. Res. Bull. 5, 101.

Fitzgerald, R. W., and Gantzel, P., 1970. X-ray energy spectrometry in the $0.1-10 \AA$ range. In Energy Dispersion X-ray Analysis, S. T. P. 485, American Society for Testing and Materials. In press.

Prospero, J. M. and Bonatti, E., 1969. Continental dust in the atmosphere of the Eastern Equatorial Pacific. J. Geophys. Res. 74, 3362.

Rex, R. W., 1969. X-ray mineralogy studies - Leg I. In Ewing, M. et al., 1969. Initial Reports of the Deep Sea Drilling Project, Volume I. Washington (U. S. Government Printing Office) 354 .

von der Borch, C. C., Nesteroff, W. D. and Galehouse, J. S., 1970. Iron-rich sediments cored during Leg 8 of the Deep Sea Drilling Project. Tracey, J. I. et al., 1971, Initial Reports of the Deep Sea Drilling Project, Volume VIII. Washington (U. S. Government Printing Office) in press.

von der Borch, C. C. and Rex, R. W., 1970. Amorphous iron oxide precipitates in sediments cored during Leg 5, Deep Sea Drilling Project. In Mc Manus, D. A. et al., 1970, Initial Reports of the Deep Sea Drilling Project, Volume V. Washington (U. S. Government Printing Office) 541.

Windom, H. L., 1969. Atmospheric dust records in permanent snowfields: Implications to marine sedimentation. Bull. Geol. Soc. Am. 80, 761. 

Plate 1

Electron Micrograph

Sample 7-66.0-8-3, 11-12 cm. Fine-grained palygorskite (fibers) and montmorillonite, with coarser-grained terrigenous minerals. 
PLATE 1

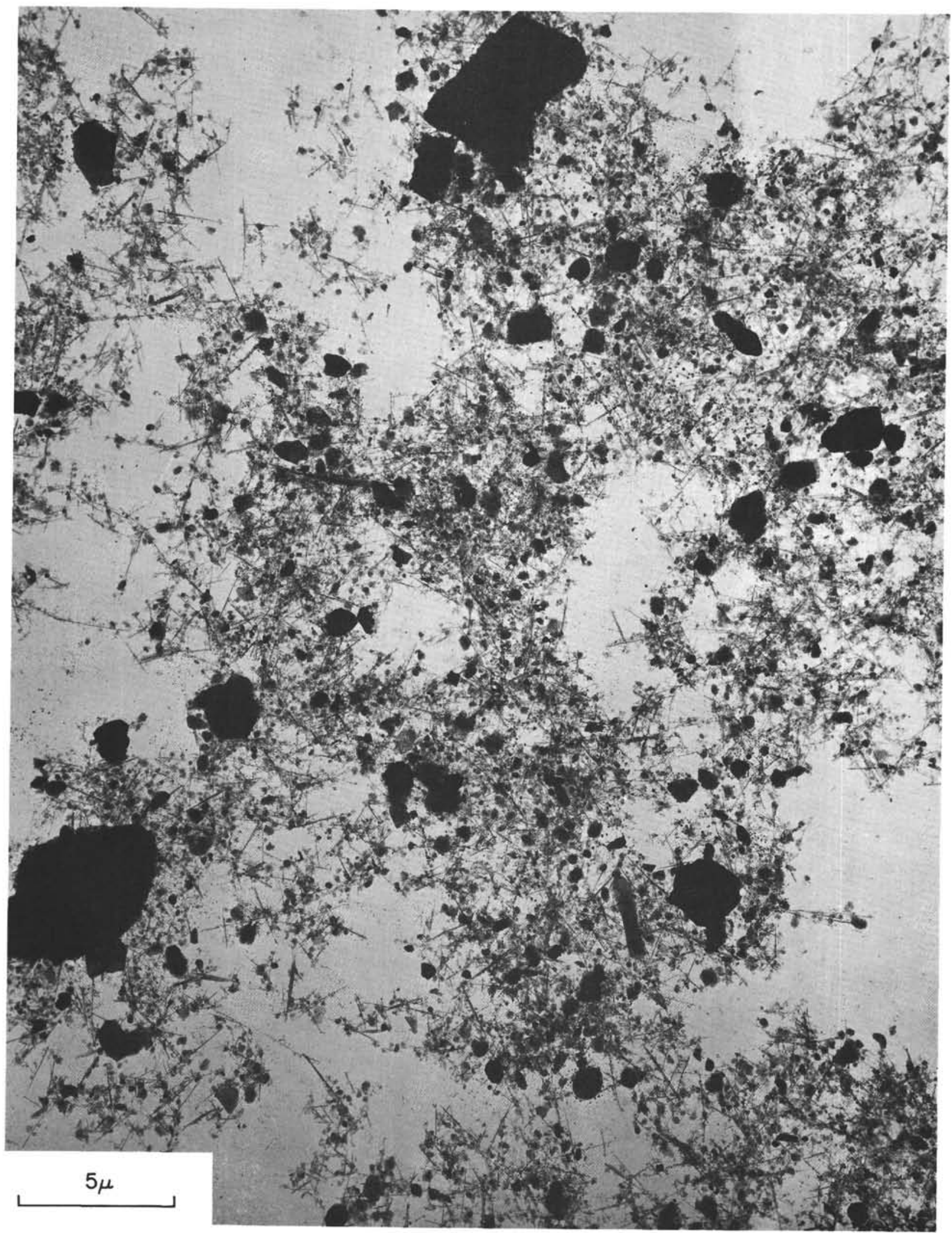


Plate 2

Electron Micrograph

Sample 7-66.0-9-3, $127-128 \mathrm{~cm}$. Crystal of heulandite/clinoptilolite (?) with palygorskite and montmorillonite. 
PLATE 2

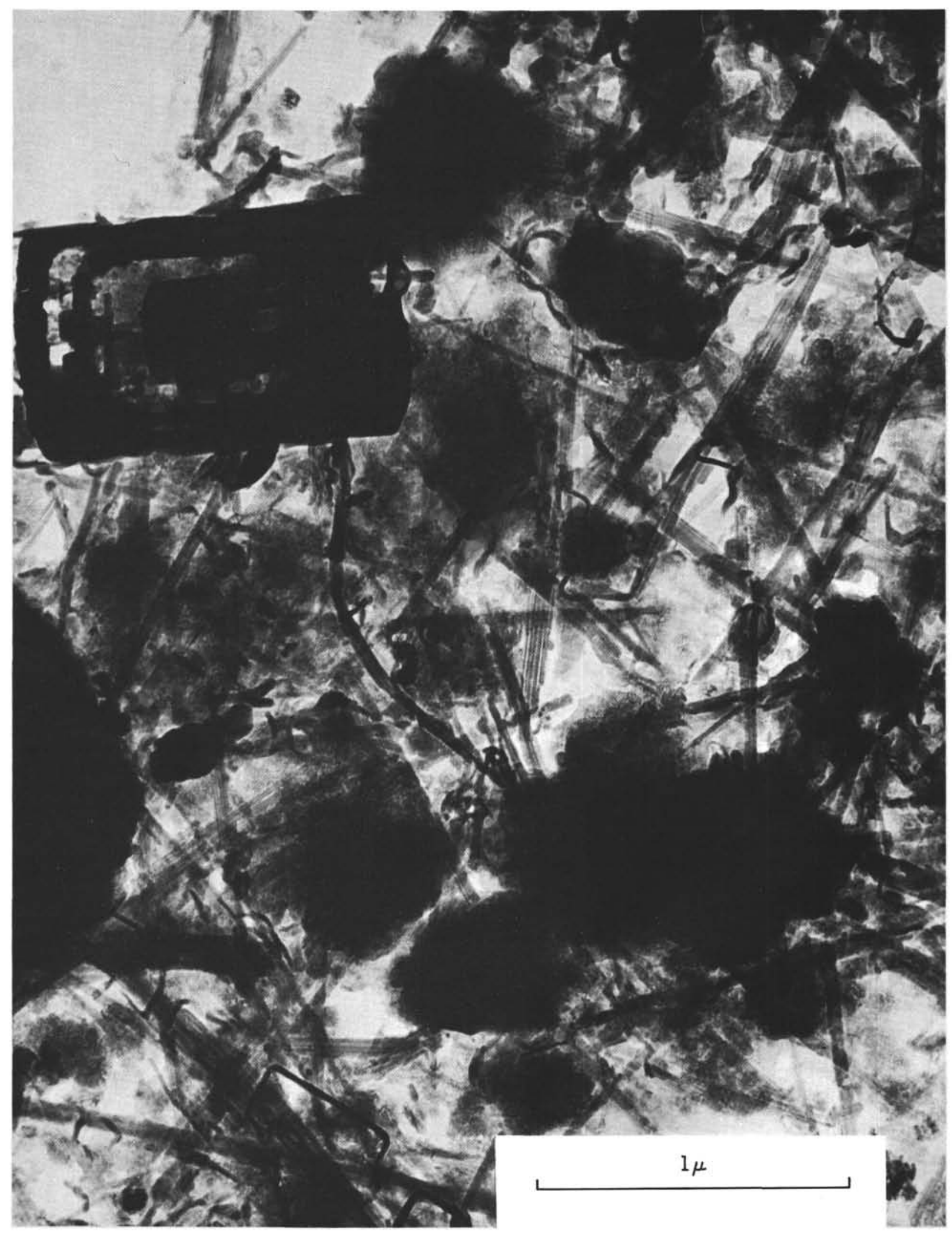


Plate 3

Electron Micrograph

Sample 7-66.0-9-3, 38-39 cm. Fine-grained amorphous iron-manganese oxide with crystals of goethite. 
PLATE 3

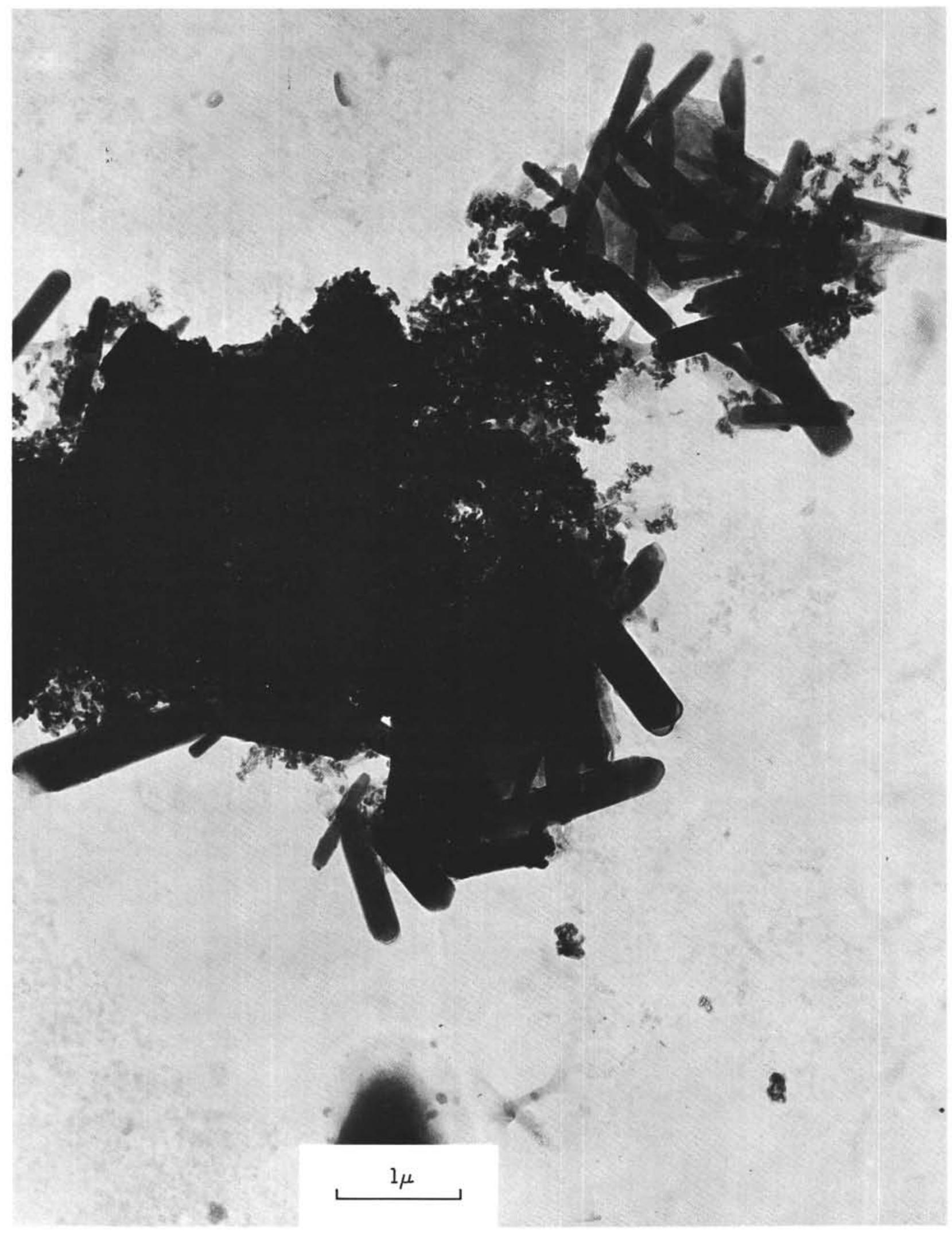

